Check for updates

Cite this: RSC Adv., 2019, 9, 11396

\title{
Construction of a water-soluble and photostable rubropunctatin/ $\beta$-cyclodextrin drug carrier
}

\author{
Zhenzhen Ren, ${ }^{a}$ Yanan $\mathrm{Xu}{ }^{\mathrm{a}}$ Zhenxin Lu, ${ }^{\mathrm{a}}$ Zhenzhen Wang, ${ }^{\mathrm{a}}$ Chengqun Chen, ${ }^{\mathrm{b}}$ \\ Yanghao Guo, ${ }^{c}$ Xianai Shi, ${ }^{c}$ Feng $\mathrm{Li}^{\mathrm{c}}{ }^{\mathrm{C}}$ Jianmin Yang ${ }^{\mathrm{c}}$ and Yunquan Zheng (D) *ac
}

The purpose of the current study was to construct a $\beta$-cyclodextrin drug carrier for rubropunctatin to improve its water solubility and light stability for future cytotoxicity studies. The inclusion complexation behavior of rubropunctatin with $\beta$-cyclodextrin was investigated using FESEM, FT-IR and XRD. A molecular docking study was performed to elucidate the most probable inclusion structure. The inclusion complex could be completely dispersed in water and had a small size of $121.87 \pm 2.13 \mathrm{~nm}(n=$ 3), a good PDI (0.320 \pm 0.017$)$, and an acceptable potential value of $-27.7 \pm 0.32 \mathrm{mV}(n=3)$. Furthermore, the stability of the rubropunctatin in water under light irradiation was found to be greatly enhanced after being encapsulated in cyclodextrin, and it exhibited a retention rate of over $70 \%$ vs. $10.17 \%$. In addition, the cytotoxicity of the inclusion complex was evaluated by MTT assay and Annexin V-FITC/PI detection using cervical adenocarcinoma HeLa cells. The results showed that the inclusion complex had comparable toxicity compared to rubropunctatin solubilized with $0.4 \%$ DMSO. More importantly, the formation of the inclusion complex contributed greatly to the intensification of the bioavailability of rubropunctatin because the use of organic solvent was avoided.

Received 16th January 2019

Accepted 24th March 2019

DOI: $10.1039 / \mathrm{c} 9 \mathrm{ra00379g}$

rsc.li/rsc-advances joined to form a hydrophobic cavity structure. ${ }^{12}$ Cyclodextrins are widely used as delivery systems in food, drug, cosmetics and other industries because of their low toxicity and low immunogenicity. ${ }^{13-15} \beta$-cyclodextrins are commonly employed in pharmaceutical products due to their favorable cavity size for drug molecules, high potency of cyclodextrin-mediated cytotoxicity and economic price. ${ }^{16,17}$ Once incorporated with drugs, $\beta$-cyclodextrins enhance the solubility, stability and bioavailability of the drug molecules. ${ }^{\mathbf{1 8 , 1 9}}$ As a drug carrier, an available monograph for $\beta$-cyclodextrins was published in both the US Pharmacopoeia/National Formulary (USP 23/NF 18, 1995) and European Pharmacopoeia (3rd edn, 1997). ${ }^{20}$ Moreover, $\beta$-cyclodextrins, in addition to $\alpha$-cyclodextrins and $\gamma$-cyclodextrins, are listed on the FDA's GRAS (Certified Safety) list. ${ }^{21}$

Investigations into $\beta$-cyclodextrin inclusion complexes have emerged, one after another. Brexin was the first oral commercially available tablet containing $\beta$-cyclodextrin as a carrier. Pharmacokinetic studies have demonstrated that a piroxicam $/ \beta$ cyclodextrin inclusion complex exhibits faster dissolution and higher wettability than piroxicam, and significantly reduces the irritation caused by drugs in the intestine because of the insertion of drug molecules into the cavity of cyclodextrin. ${ }^{22}$ Bandarkar et al. used ball milling technology to prepare MLX/ $\beta$-cyclodextrin inclusion complex with enhanced water solubility and dissolution rate, which overcomes the lack of feasibility associated with expanding the manufacturing process. $^{23}$ This achievement brought the dawn of the actual production and application of $\beta$ cyclodextrin. Nelfinavir Mesylate (NM), an anti-HIV drug,
${ }^{a}$ College of Chemistry, Fuzhou University, 2 Xueyuan Road, Fuzhou 350116, Fujian, China. E-mail: yunquanzheng@fzu.edu.cn; Fax: +86-591-22866234; Tel: +86-59122866234

${ }^{b}$ Department of Chemical Engineering, Fuzhou University Zhicheng College, 523 Gongye Road, Fuzhou 350002, China

${ }^{c}$ Fujian Key Laboratory of Medical Instrument and Pharmaceutical Technology, Fuzhou University, 2 Xueyuan Road, Fuzhou 350116, China 
exhibited increased solubility with decreased crystallinity and an enhanced intestinal absorption rate when incorporated into the cavity of $\beta$-cyclodextrin. ${ }^{24}$ Li et al. synthesized $\beta$-cyclodextrinconjugated hyaluronan hydrogel as a drug carrier suitable for wound healing. Results showed that the high loading capacity and sustained drug delivery was caused by the interaction between $\beta$-cyclodextrin and the drug. ${ }^{25}$ Modified cyclodextrin has been prepared as an injectable drug carrier, one successful example being Sporanox. ${ }^{26}$ Related studies have shown that the formation of inclusion complexes can be characterized by UV-vis, SEM, Fourier transform-infrared spectroscopy, molecular docking, NMR, X-ray diffraction, and other techniques. ${ }^{27,28}$

So far, no research has been conducted on inclusion complexes comprising $\beta$-cyclodextrin and rubropunctatin. However, rubropunctatin, as a promising natural dualanticancer agent, is water-insoluble and light-insoluble. In our present work, we report the preparation and characterization of an inclusion complex formed between rubropunctatin and $\beta$ cyclodextrin. The inclusion complex was characterized using FT-IR, FESEM and XRD. The most probable structure of the inclusion complex was proposed by a molecular docking study. Furthermore, the dispersibility, photostability and cytotoxicity of the inclusion complex was studied.

\section{Experimental section}

\subsection{Materials}

The Monascus pigment, rubropunctatin, was purified in our laboratory. ${ }^{29}$ Cervical adenocarcinoma HeLa cells were purchased from Cell Resource Center of Shanghai Biological Sciences Institute (Chinese Academy of Sciences, Shanghai, China). DMEM medium was obtained from Gibco BRL (Gaithersburg, MD, USA). Fetal bovine serum (FBS) was obtained from Invitrogen GmbH (Karlsruhe, Germany). Gentamicin, L-glutamine and 1,3diphenylisobenzofuran were purchased from Sigma (St. Louis, MO, USA). PBS ( $\mathrm{pH}$ 7.2) was obtained from Shanghai Yuanpei Biotechnology Co., Ltd. (Shanghai, China). Annexin-V/PI staining kits were purchased from KGI Biotechnology Development Co., Ltd. (Nanjing, China). $\beta$-Cyclodextrin was purchased from Shanghai Yuanye Biological Technology Co., Ltd. (Shanghai, China). All other reagents (analytical grade) were purchased from Sinopharm Chemical Reagent Co., Ltd. (Shanghai, China) and used as received without additional purification.

\subsection{Cell culture}

HeLa cells were cultured with DMEM medium supplemented with $10 \%(\mathrm{v} / \mathrm{v}) \mathrm{FBS}, 40 \mathrm{U} \mathrm{mL}^{-1}$ gentamicin, and $20 \mathrm{mmol} \mathrm{L}^{-1} \mathrm{~L}^{-}$ glutamine. The culture was incubated at $37{ }^{\circ} \mathrm{C}$ in a humidified atmosphere of $5 \% \mathrm{CO}_{2}$ in an incubator (Series $8000 \mathrm{WJ}$, Thermo Scientific, USA). The medium was replenished every second day and the cells were subcultured after reaching confluence.

\subsection{Preparation of rubropunctatin/ $\beta$-cyclodextrin inclusion complex}

The molar ratio of rubropunctatin to $\beta$-cyclodextrin in the entire reaction was $1: 1 .^{30} 0.3244 \mathrm{~g}$ of $\beta$-cyclodextrin was added to
$20 \mathrm{~mL}$ of ultrapure water and dissolved in a $60^{\circ} \mathrm{C}$ water bath to prepare a cyclodextrin saturated solution. Under stirring, $2 \mathrm{~mL}$ of rubropunctatin acetone solution $\left(0.0506 \mathrm{~g} \mathrm{~mL}^{-1}\right)$ was slowly added, and the reaction was heated for $6 \mathrm{~h}$. After cooling, it was pre-frozen for $24 \mathrm{~h}$ in an ultra-low temperature refrigerator (ULTS1368, Thermo Fisher (Suzhou) Instrument Co., Ltd., China) at $-80{ }^{\circ} \mathrm{C}$, and then freeze-dried in a freeze dryer (SCIENTZ-30ND, Ningbo Xinzhi Biotechnology Co., Ltd. China).

\subsection{Dispersion experiment in water}

$0.020 \mathrm{~g}$ of rubropunctatin and rubropunctatin/ $\beta$-cyclodextrin inclusion complex were respectively weighed and dissolved in test tubes each containing $4 \mathrm{~mL}$ of water. The samples were then allowed to stand for $5 \mathrm{~min}$ to observe the color and clarification of the solutions. After the above-mentioned inclusion complex was diluted with distilled water for a certain multiple, the particle size distribution and zeta potential were measured using a nanometer particle size analyzer (Zetasizer Nano ZS, Malvern Corporation, UK).

\subsection{FESEM assay}

To compare the surface morphology of rubropunctatin, $\beta$ cyclodextrin, their physical mixtures (the molar ratio of rubropunctatin to $\beta$-cyclodextrin was $1: 1$ ) and the rubropunctatin $/ \beta$ cyclodextrin inclusion complex, FESEM measurements were conducted at $0.2-30 \mathrm{kV}$ on a field emission scanning electron microscope (Nova NanoSEM 230, American FEI Company, USA). For this purpose, each sample was fixed on a brass stub using double-sided tape and then was sputter coated with a conductive layer of gold using a sputter coating system (K550X, Quorum Technologies Ltd, UK). We used Image J to analyze the FESEM images.

\subsection{FT-IR assay}

FT-IR spectra were obtained for rubropunctatin, $\beta$-cyclodextrin, the physical mixture and the rubropunctatin/ $\beta$-cyclodextrin inclusion complex samples using a Fourier infrared spectrometer (Nicolet 410, American Nichols, USA). The samples were pressed with $\mathrm{KBr}$ to form pellets and recorded at frequencies from $4000-200 \mathrm{~cm}^{-1}$.

\subsection{Powder X-ray diffraction (XRD)}

Monochromatic $\mathrm{Cu} \mathrm{K} \alpha$ radiation (wavelength $=1.540598 \AA$ ) was produced by a XPERT-3 X-ray diffractometer (Netherlands Panalytical, Netherlands). The powdery samples were packed tightly into rectangular aluminum cells. Then, the packaged samples were exposed to the X-ray beam at diffraction angles, $2 \theta$, from 5 to 60 . The diffracted radiation was detected with a proportional detector.

\subsection{Molecular docking study}

A molecular docking study was performed to investigate the binding mode between rubropunctatin and $\beta$-cyclodextrin using Autodock Vina 1.1.2. ${ }^{31}$ The three-dimensional (3D) structure of $\beta$-cyclodextrin was extracted from the PDB file 
3CGT, which was downloaded from the RCSB Protein Data Bank (http:/www.rcsb.org/pdb/home/home.do). The 2D structure of rubropunctatin was drawn using ChemBioDraw Ultra 14.0 and converted into a 3D structure using ChemBio3D Ultra 14.0 software. The AutoDockTools 1.5.6 package was employed to generate the docking input files. ${ }^{32}$ The ligand was prepared for docking by merging non-polar hydrogen atoms and defining rotatable bonds. The search grid of the $\beta$-cyclodextrin was identified as center_x: 58.584, center_y: 11.891, and center_z: 8.835, with dimensions of size_x: 15 , size_y: 15, and size_z: 15 . In order to increase the docking accuracy, the value of exhaustiveness was set to 20. For Vina docking, the default parameters were used if not mentioned otherwise. The best-scoring pose as judged by the Vina docking score was chosen and visually analyzed using PyMoL 1.7.6 software (http://www.pymol.org/).

\subsection{Light stability assay}

To research the light stability, the rubropunctatin/ $\beta$-cyclodextrin inclusion complex was dissolved in $80 \%$ ethanol solution, sonicated under a $400 \mathrm{~W}$ probe ultrasound system for $2 \mathrm{~min}$, at a final concentration of $5 \mathrm{mg} \mathrm{mL} \mathrm{m}^{-1}$, and then the above solutions were divided into seven parts on average. The absorbance of one of the samples was measured with an ultraviolet-visible spectrometer at 300-800 $\mathrm{nm}$ to determine the maximum absorption peak position of the inclusion complex, while the other six sets were exposed to a tungsten halogen lamp $(500 \mathrm{~W}$, wavelengths: 597-622 nm). The irradiation was stopped at regular intervals $(0.5 \mathrm{~h}, 1 \mathrm{~h}, 1.5 \mathrm{~h}, 2 \mathrm{~h}, 3 \mathrm{~h}$, and $4 \mathrm{~h})$ to detect absorbance at $506 \mathrm{~nm}$ under the same conditions. According to the above steps, the control group of rubropunctatin (detection wavelength: $488 \mathrm{~nm}$ ) was set. The pigment retention rate was calculated according to the following equation:

Retention rate after illumination $=$ absorbance at $x \mathrm{~h}$ with light/ absorbance without light

\subsection{Cytotoxicity assay}

MTT (3-(4,5-dimethylthiazol-2-yl)-2,5-diphenyltetrazolium bromide) assay was carried out to investigate the bioactivity of the rubropunctatin/ $\beta$-cyclodextrin inclusion complex and rubropunctatin solubilized with or without $0.4 \%$ DMSO. HeLa cells were firstly seeded to three 96 -well plates at a seeding density of $1 \times 10^{4}$ cells per well in $200 \mu \mathrm{L}$ complete medium, and incubated in a $37{ }^{\circ} \mathrm{C}$ humidified incubator with $5 \% \mathrm{CO}_{2}$. After $24 \mathrm{~h}$ of incubation, the medium in the 96-well plate was discarded, the cells were rinsed with PBS three times, and 200 $\mu \mathrm{L}$ of medium was added (medium containing the inclusion complex, or medium containing rubropunctatin solubilized with or without $0.4 \%$ DMSO), each in sextuplicate. It is important to note that the concentration of rubropunctatin in the inclusion complex was the same as that in the rubropunctatin solution (solubilized with or without $0.4 \%$ DMSO) and all the final concentrations of rubropunctatin were $0 \mu \mathrm{mol} \mathrm{L} \mathrm{L}^{-1}, 10$ $\mu \mathrm{mol} \mathrm{L}{ }^{-1}, 25 \mu \mathrm{mol} \mathrm{L}^{-1}, 50 \mu \mathrm{mol} \mathrm{L}{ }^{-1}, 75 \mu \mathrm{mol} \mathrm{L}^{-1}$ and $100 \mu \mathrm{mol}$
$\mathrm{L}^{-1}$. Every plate was kept in the dark for studying toxicity. After the cells were grown for another $24 \mathrm{~h}, 100 \mu \mathrm{L}$ of MTT solution (0.5 $\mathrm{mg} \mathrm{mL} \mathrm{mL}^{-1}$ in $\mathrm{pH}$ 7.2 PBS) was added to each well. After incubation for $4 \mathrm{~h}$, the medium containing unreacted MTT was removed carefully, and $100 \mu \mathrm{L}$ DMSO was added to each well to dissolve the produced blue formazan. The absorbance was measured at a wavelength of $570 \mathrm{~nm}$ using an automated plate reader (SH-1000, Corona Electric, Japan). The results were expressed as values of mean $\pm \mathrm{SD}$. The $\mathrm{IC}_{50}$, cytotoxic concentration for $50 \%$ cell death, was calculated by probit regression (SPSS 17.0 software).

\subsection{Annexin V-FITC/PI assay}

In order to further evaluate whether rubropunctatin can continue to play a role in inducing apoptosis after inclusion by $\beta$-cyclodextrin, the Annexin V-FITC/PI detection kit was applied. An analysis of phosphatidylserine on the outer leaflet of apoptotic cell membranes was performed using Annexin-V and PI to distinguish between apoptotic and necrotic cells. HeLa cells that were both Annexin-V and PI negative represented survivals, Annexin-V positive and PI negative represented the early phase of apoptosis, and both Annexin-V and PI positive represented the late apoptotic/necrotic stage. After treatment, cells $\left(1 \times 10^{5}\right.$ cells per $\left.\mathrm{mL}\right)$ were stained with Annexin-V and PI according to the manufacturer's instructions. $500 \mu \mathrm{L}$ of Annexin binding buffer was added to each tube, and stained cells were analyzed using a flow cytometer (COULTER EPICS XL, American Beckman Company, USA).

\subsection{Statistical analysis}

The results were expressed as the mean \pm standard deviation (SD) from three independent experiments. Statistical analysis was performed by using SPSS 17.0 software, origin 9.0 and prism 5.0. Group differences were assessed by Student's $t$ test, and considered significant for $p<0.05(*)$, and $p<0.001(* * *)$.

\section{Results}

\subsection{Dispersion test}

Monascus rubropunctatin is a deep red powder that is insoluble in water. $^{33}$ Certain masses of rubropunctatin and rubropunctatin/ $\beta$-cyclodextrin inclusion complex were separately dissolved in the same volume of distilled water, and were allowed to stand for $5 \mathrm{~min}$ to obtain sample solutions to be tested.

In Fig. 1c, we can see that most of the rubropunctatin sinks to the bottom, a small amount floats on the liquid surface, and a few particles are suspended in the aqueous solution (Fig. 1c(i)), but the inclusion complex is uniformly dispersed in the solution, which is orange-yellow in color (Fig. 1c(ii)). The rubropunctatin solution was colorless and transparent after filtering through a $0.22 \mu \mathrm{m}$ filter (figure not shown). However, the color of the inclusion complex solution was slightly lighter than that before filtering. Finally, the average particle size of the inclusion complex was measured to be $121.87 \pm 2.13 \mathrm{~nm}(n=3)$ (Fig. 1a) with a good PDI $(0.320 \pm 0.017)(n=3)$ demonstrating 
that the solution had good homogeneity. ${ }^{34}$ Regarding the surface charge, the potential value of the inclusion complex was $-27.7 \pm 0.32 \mathrm{mV}(n=3)$ (Fig. 1b), which supported the standpoint that the inclusion complex solution possesses stability because its particles exhibit sufficient interparticle repulsion to prevent aggregation. ${ }^{35}$ It was reported by Lu et al. that when the zeta potential of a solution is high, a relatively stable system is achieved, because the repulsive force exceeds the attraction. ${ }^{36,37}$ However, the potential value of $-27.7 \pm 0.32 \mathrm{mV}$ is only in an acceptable potential range and is not exceptional. Compared with the rubropunctatin, the formation of the rubropunctatin/ $\beta$-cyclodextrin inclusion complex significantly improved the solubility of rubropunctatin in water.

\subsection{Characterization of rubropunctatin/ $\beta$-cyclodextrin inclusion complex}

3.2.1 FESEM analysis. When the drug molecule enters the cyclodextrin cavity, its crystallinity is reduced or even lost, which will change the specific position and spatial structure of the drug molecule. Thus, the morphologies of rubropunctatin, $\beta$-cyclodextrin, their physical mixture and the inclusion complex were analyzed using scanning electron microscopy to judge whether a clathrate is formed or not. ${ }^{38}$

As shown in Fig. 2, the $\beta$-cyclodextrin particles appear as block crystals with a smooth surface (Fig. 2b), and rubropunctatin exists as a rod-like crystal with a smooth surface (Fig. 2a). The shape of the particles in the rubropunctatin/ $\beta$ cyclodextrin inclusion complex is obviously different from that of the $\beta$-cyclodextrin and rubropunctatin particles, and a flaky structure with many lamellar crystals on the surface can be seen in Fig. 2d. At the same time, we observed no changes in the surface structure of the physical mixture (Fig. 2c), whose morphology was a simple mix of the rod-shaped rubropunctatin and the bulk $\beta$-cyclodextrin. The change of the morphology of rubropunctatin in the inclusion complex and the lack of structural change in physical mixture confirmed the formation of the rubropunctatin/ $\beta$-cyclodextrin inclusion complex.

3.2.2 Fourier-transform infrared spectroscopy (FTIR). The infrared band usually shifts or the intensity changes after the guest molecule is encapsulated by $\beta$-cyclodextrin. ${ }^{39}$ In this study, we determined the FT-IR spectrum of rubropunctatin, $\beta$ cyclodextrin, the physical mixture and the rubropunctatin/ $\beta$ cyclodextrin inclusion complex from 4000 to $500 \mathrm{~cm}^{-1}$.

The FT-IR spectrum of $\beta$-cyclodextrin (Fig. 3c) is characterized by a broad band with a transmittance peak of $3288 \mathrm{~cm}^{-1}$ (for the symmetric and asymmetric - $\mathrm{OH}$ stretching vibration due to the many intermolecular hydrogen bonds), $2926 \mathrm{~cm}^{-1}$ (for the $\mathrm{C}-\mathrm{H}$ stretching vibration), $1023 \mathrm{~cm}^{-1}$ (for the symmetric $\mathrm{C}-\mathrm{O}-\mathrm{C}$ stretching vibration). The main absorption peaks of rubropunctatin (Fig. 3d) are located at $2929 \mathrm{~cm}^{-1}$ (for the $\mathrm{C}-\mathrm{H}$ stretching vibration), $1725 \mathrm{~cm}^{-1}$ (for the $\mathrm{C}=\mathrm{O}$ stretching vibration), $1513 \mathrm{~cm}^{-1}$ (for the $\mathrm{C}=\mathrm{C}$ stretching vibration), $884 \mathrm{~cm}^{-1}$ (for the $=\mathrm{C}-\mathrm{H}$ out-of-plane rocking vibration). The FT-IR spectrum of the physical mixture (Fig. 3b) was derived by superimposing the spectra of rubropunctatin and $\beta$-cyclodextrin. However, Fig. 3a exhibits the modifications in the vibrational modes of rubropunctatin and $\beta$-cyclodextrin. The $\mathrm{C}=\mathrm{O}$ stretching vibration $\left(1725 \mathrm{~cm}^{-1}\right), \mathrm{C}=\mathrm{C}$ stretching vibration $\left(1531 \mathrm{~cm}^{-1}\right)$ and $=\mathrm{C}-\mathrm{H}$ stretching vibration $\left(884 \mathrm{~cm}^{-1}\right)$ of rubropunctatin are absent in the inclusion complex because rubropunctatin is bound to the cyclodextrin molecule cavity. The transmission intensity at $1023 \mathrm{~cm}^{-1}$ of $\beta$-cyclodextrin is greatly weakened, demonstrating the diminished interaction among the inclusion complex molecules. A good indication of the formation of the inclusion complex is that the broad $\mathrm{O}-\mathrm{H}$ band of $\beta$-cyclodextrin at $3288 \mathrm{~cm}^{-1}$ was found to be narrowed in the FT-IR spectrum. ${ }^{\mathbf{4 0}}$
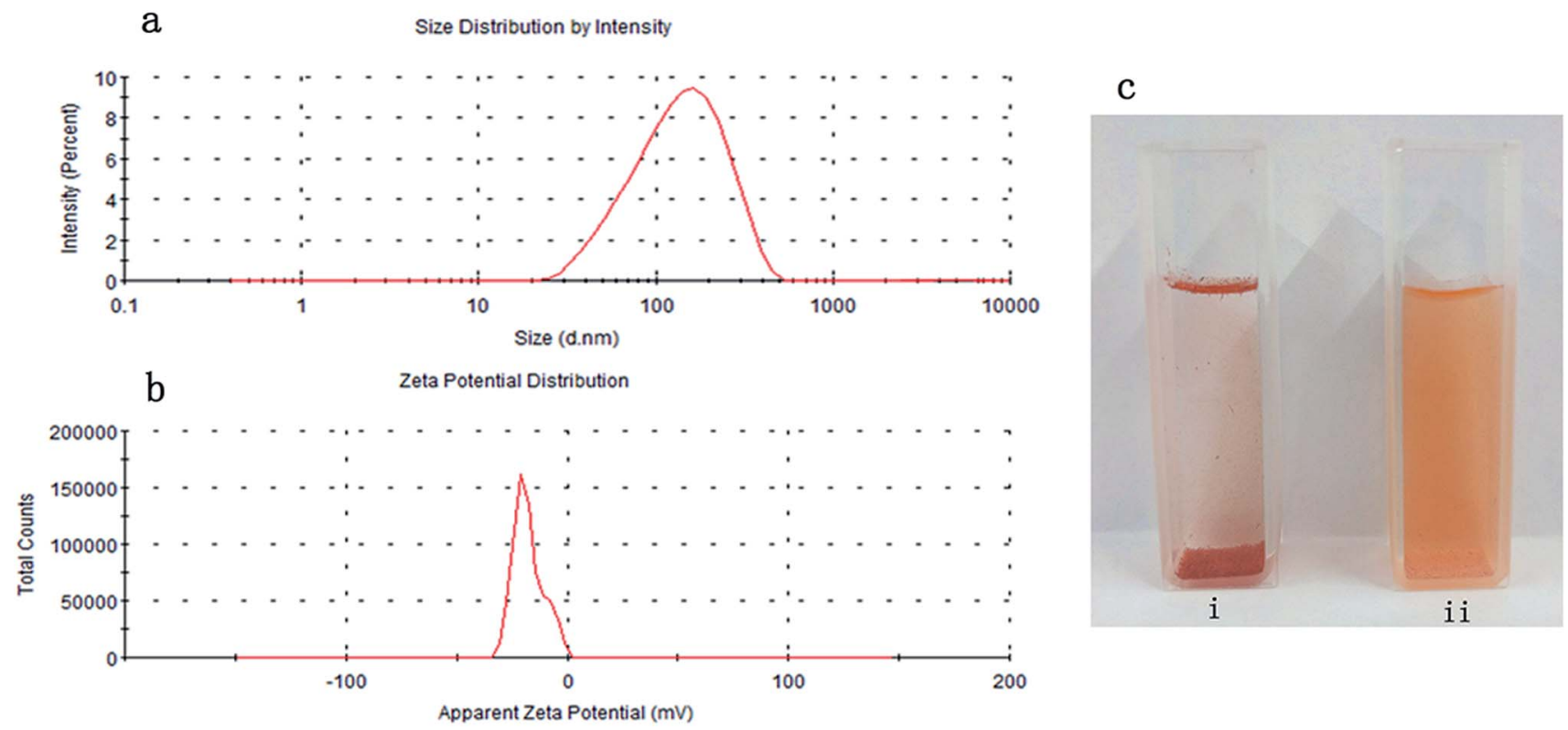

Fig. 1 Characterization of rubropunctatin/ $\beta$-cyclodextrin inclusion complex in water: (a) particle size distribution spectrum; (b) the zeta potential. (c) Photograph showing differences in dispersion: (i) rubropunctatin; (ii) rubropunctatin/ $\beta$-cyclodextrin inclusion complex in water. 


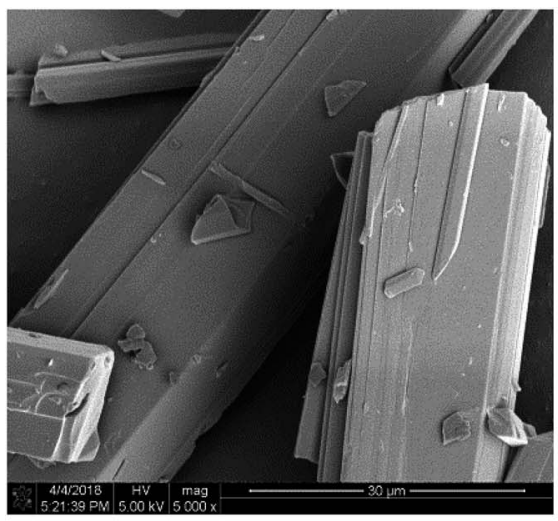

(a)

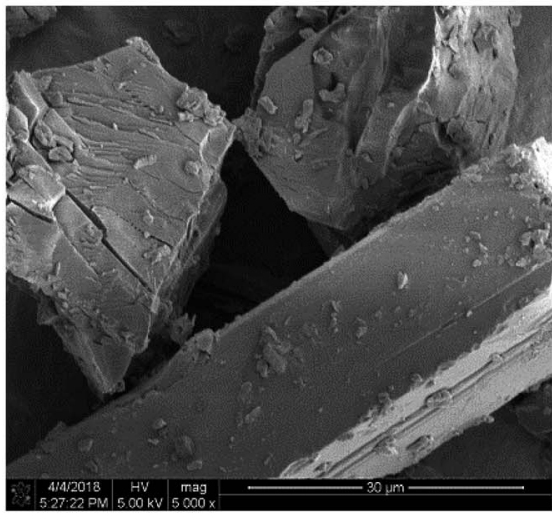

(c)

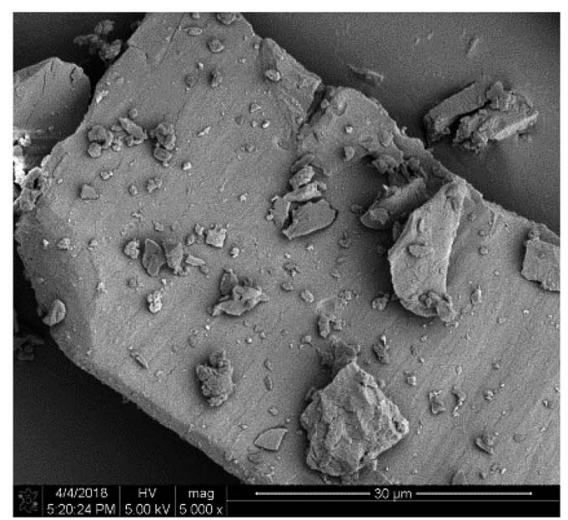

(b)

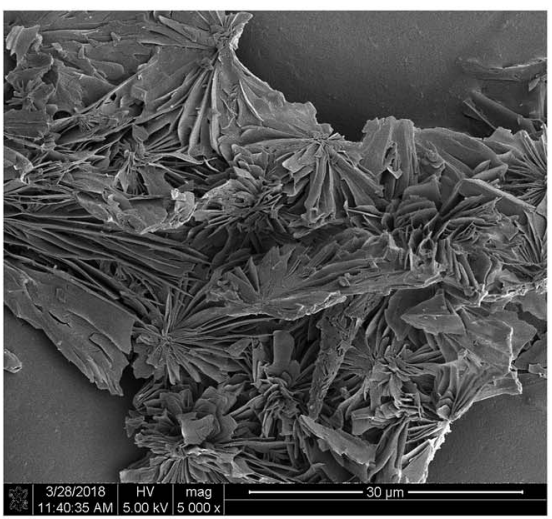

(d)

Fig. 2 The FESEM images of (a) rubropunctatin, (b) $\beta$-cyclodextrin, (c) $1: 1$ molar ratio physical mixture, (d) rubropunctatin/ $\beta$-cyclodextrin inclusion complex.

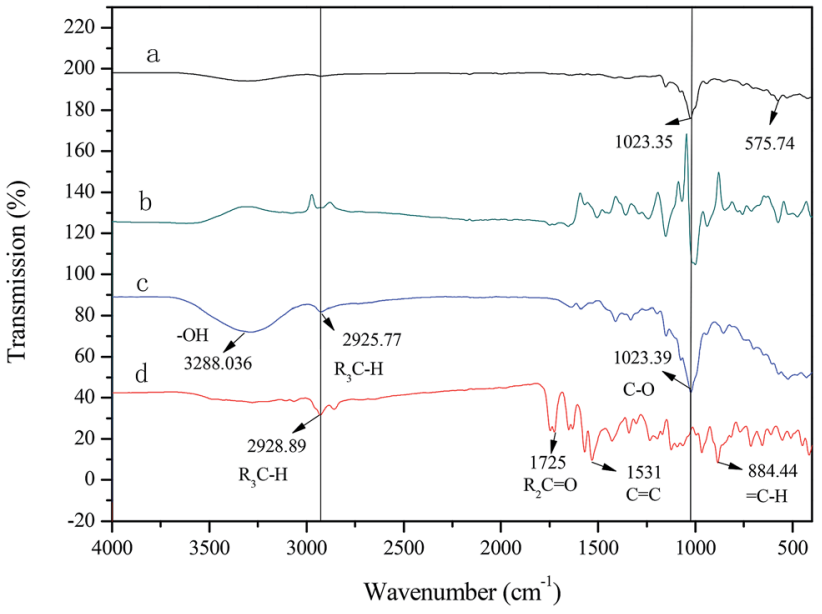

Fig. 3 FT-IR spectra for (a) rubropunctatin/ $\beta$-cyclodextrin inclusion complex, (b) $1: 1$ molar ratio physical mixture, (c) $\beta$-cyclodextrin, (d) rubropunctatin.

3.2.3 XRD results. Further evidence for the formation of the rubropunctatin/ $\beta$-cyclodextrin inclusion complex was obtained from XRD, which has been proven to be an effective method for the analysis of inclusion complexes. ${ }^{41}$ The XRD pattern of the 1:1 molar ratio physical mixture (Fig. 4c) is basically a combination of the signal profiles of rubropunctatin (Fig. 4a) and $\beta$-cyclodextrin (Fig. 4b), confirming that no chemical association has occurred. By contrast, the prepared inclusion complex (Fig. 4d) showed a sharply distinct profile from that of the physical mixture, indicating a new crystalline phase and suggesting inclusion behavior between rubropunctatin and $\beta$-cyclodextrin. ${ }^{42,43}$ Simultaneously, most of the rubropunctatin had complexed with $\beta$-cyclodextrin resulting in none of the characteristic peaks of rubropunctatin being present in the XRD pattern of the rubropunctatin/ $\beta$-cyclodextrin inclusion complex.

\subsection{Molecular docking results}

The rubropunctatin was docked into the binding pocket of the $\beta$-cyclodextrin and the results are presented in Fig. 5. The 3D structures of rubropunctatin and $\beta$-cyclodextrin are separately shown in Fig. 5a and b. The evaluated binding energy between the $\beta$-cyclodextrin and rubropunctatin was found to be $-5.6 \mathrm{kcal} \mathrm{mol}^{-1}$. The rubropunctatin adopted a compact conformation and was wrapped by $\beta$-cyclodextrin. Detailed analysis revealed two key hydrogen bond interactions with bond 


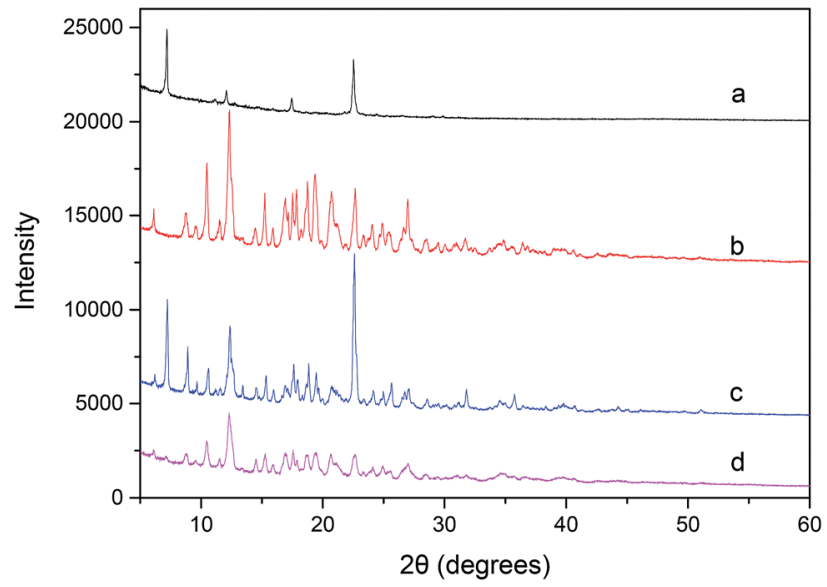

Fig. 4 XRD patterns: (a) rubropunctatin; (b) $\beta$-cyclodextrin; (c) $1: 1$ molar ratio physical mixture; (d) rubropunctatin/ $\beta$-cyclodextrin inclusion complex.

lengths of 1.9 and $2.4 \AA$ (Fig. $5 c$ and 3e). All these interactions helped rubropunctatin to anchor to the binding site of $\beta$ cyclodextrin.

In summary, the above molecular simulations gave us a rational explanation of the interactions between the rubropunctatin and $\beta$-cyclodextrin, providing valuable information for the study of the mode of action of the rubropunctatin $/ \beta$ cyclodextrin inclusion complex. (a)

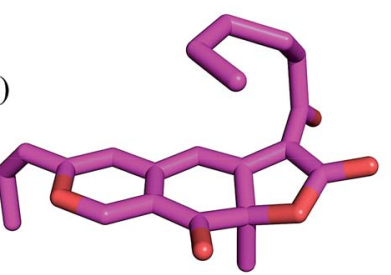

(c)

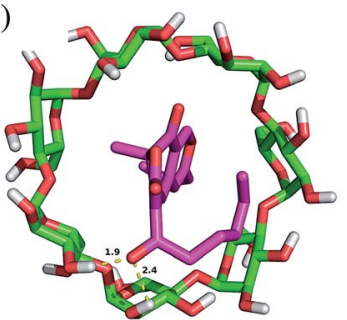

(e)

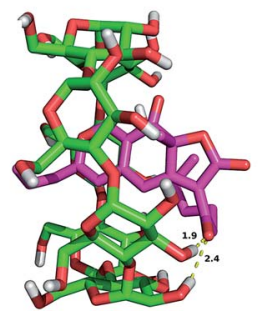

(b)

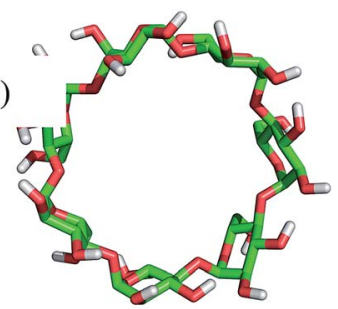

(d)

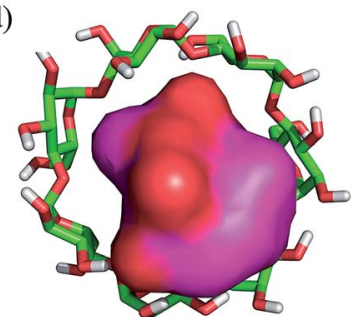

(f)

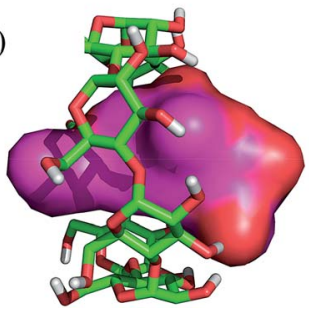

Fig. 5 3D structures of (a) rubropunctatin and (b) $\beta$-cyclodextrin. Front view and side view of the rubropunctatin/ $\beta$-cyclodextrin inclusion complex: ( $c$ and e) wireframe view, ( $d$ and $f)$ stick-ball view.

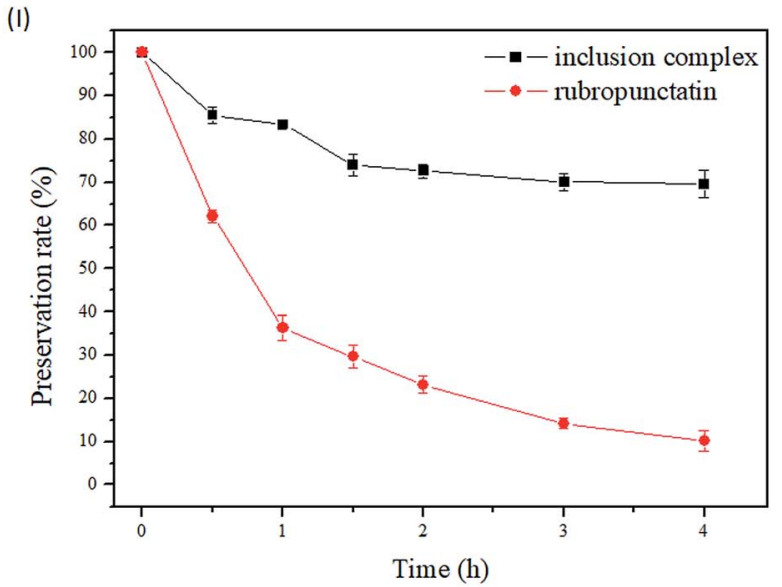

(II)
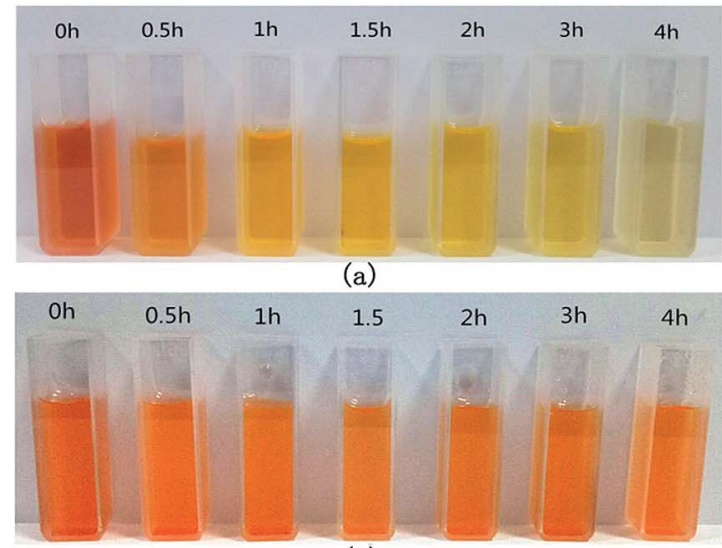

(b)

Fig. 6 (I) Changes in preservation rate of rubropunctatin and rubropunctatin/ $\beta$-cyclodextrin inclusion complex after illumination under light for different times (light source: tungsten halogen lamp, $500 \mathrm{~W}$, wavelength: 597-622 nm). (II) The influence of different periods of illumination on the color of (a) rubropunctatin and (b) rubropunctatin/ $\beta$-cyclodextrin inclusion complex solutions.

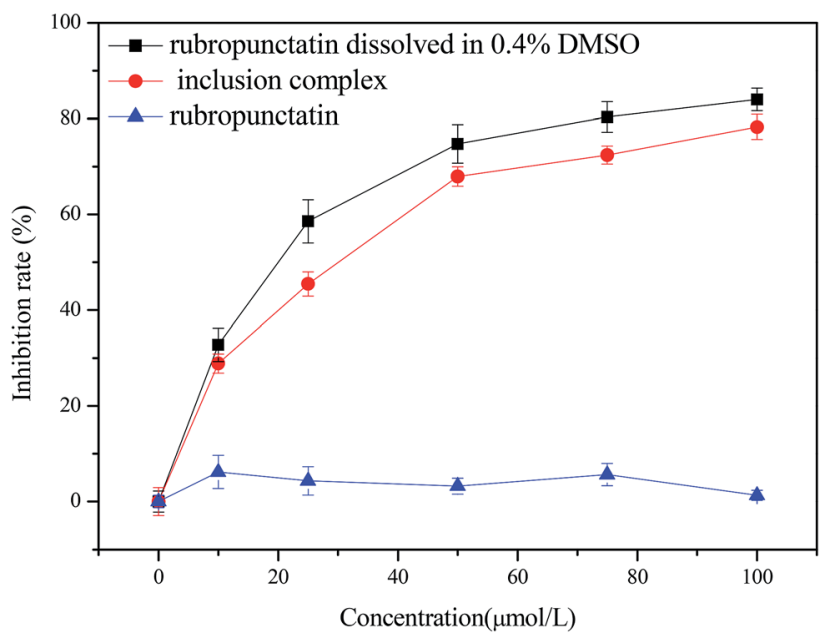

Fig. 7 Cytotoxicity of rubropunctatin/ $\beta$-cyclodextrin inclusion complex, and rubropunctatin solubilized with or without $0.4 \%$ DMSO on HeLa cells. 

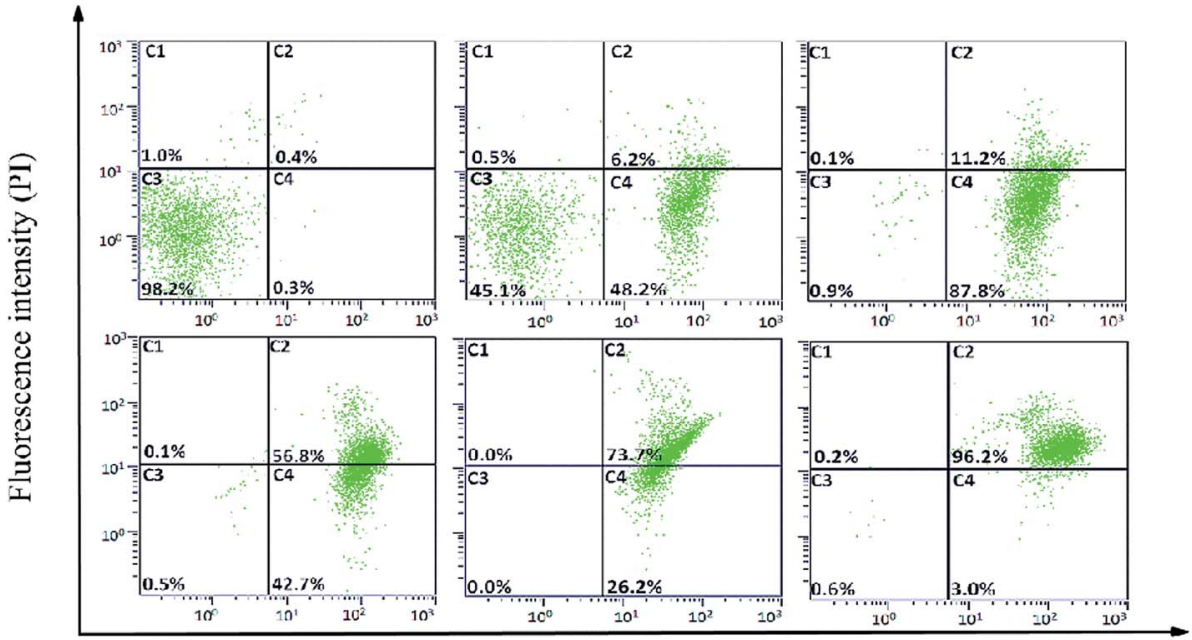

Fluorescence intensity (FITC)

(a)
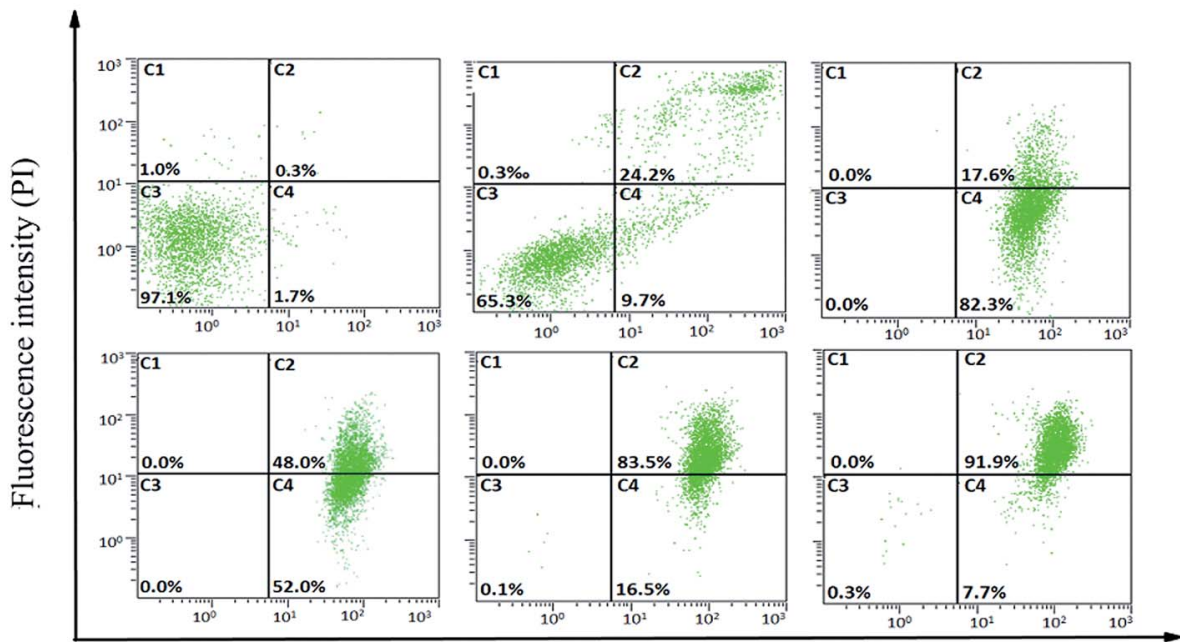

Fluorescence intensity (FITC)

(b)

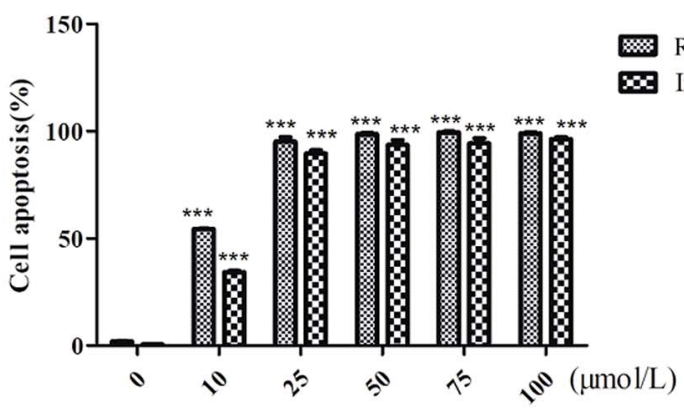

(c)

Fig. 8 Induction of apoptosis by HeLa cells (C1: dead cells; C2: late apoptotic/necrotic cells; C3: non-apoptotic cells; C4: early apoptotic cells; dosing concentration from left to right, from above to bottom is $0,10,25,50,75,100 \mu \mathrm{mol} \mathrm{L}^{-1}$ ). (a) Rubropunctatin solubilized with $0.4 \%$ DMSO. (b) Rubropunctatin/ $\beta$-cyclodextrin inclusion complex. (c) Fluorometric quantification of the apoptotic cells. 


\subsection{Light stability test}

As illustrated in Fig. 6(I), the preservation rate of rubropunctatin decreased rapidly with the extension of illumination time. At $4 \mathrm{~h}$, rubropunctatin faded significantly (Fig. 6(II)-a), and the preservation rate dropped sharply to $10.17 \%$. Compared to rubropunctatin, the preservation rate of the rubropunctatin $/ \beta$ cyclodextrin inclusion complex reduced slowly. The retention rate of the inclusion complex was $72.67 \%$ at $2 \mathrm{~h}$, which was much higher than that of rubropunctatin $(23.22 \%)$. When the irradiation time was extended to $4 \mathrm{~h}$, the retention rate was still greater than $70 \%$, and no obvious change in the color of the clathrate solution was observed (Fig. 6(II)-b).

The determination results revealed that the photocatalytic stability of the rubropunctatin/ $\beta$-cyclodextrin inclusion complex was significantly enhanced. When rubropunctatin enters the cavity of cyclodextrin, the energy of the direct action of light on rubropunctatin decreases, which reduces the probability of a photochemical reaction. The decrease of the preservation rate of the inclusion complex within $2 \mathrm{~h}$ might be caused by the photodegradation of rubropunctatin dispersed on the surface.

\subsection{In vitro cytotoxicity assay}

In this study, the in vitro cytotoxicity assays of the rubropunctatin/ $\beta$-cyclodextrin inclusion complex and rubropunctatin solubilized with or without $0.4 \%$ DMSO were evaluated on HeLa cell line and their $\mathrm{IC}_{50}$ values were compared. The antiproliferative activity of the three prepared samples to HeLa cells after $24 \mathrm{~h}$ of incubation is illustrated in Fig. 7.

First of all, it is worth noting that the free rubropunctatin did not exert cytotoxicity without being solubilized in $0.4 \%$ DMSO (Fig. 7c). However, rubropunctatin, solubilized in $0.4 \%$ DMSO (Fig. 7a) and loaded in $\beta$-cyclodextrin (Fig. 7b), decreased the viability of HeLa cells in a dose-dependent manner. The $\mathrm{IC}_{50}$ values were $26.60 \pm 0.64 \mu \mathrm{mol} \mathrm{L}^{-1}$ (rubropunctatin, solubilized in $0.4 \%$ DMSO) and $39.37 \pm 1.03 \mu \mathrm{mol} \mathrm{L}^{-1}$ (rubropunctatin, loaded in $\beta$-cyclodextrin), which are slightly lower than the value for rubropunctatin solubilized in $0.4 \%$ DMSO. The small difference in cytotoxicity may be explained by the cytotoxicity of $0.4 \%$ DMSO on cells or the incomplete release of rubropunctatin in $\beta$-cyclodextrin that had not yet had the opportunity to exert its activity.

Above all, we can conclude that the rubropunctatin/ $\beta$-cyclodextrin inclusion complex retained its cytotoxicity, not only because the inclusion complex had significant activity compared with free rubropunctatin solubilized without $0.4 \%$ DMSO, but also because the cell cytotoxicity of the inclusion complex was close to that of rubropunctatin assisted with $0.4 \%$ DMSO ${ }^{44}$ More noteworthy, the bioavailability of rubropunctatin was greatly intensified because the use of organic solvent was avoided.

\subsection{Annexin V-FITC/PI detection}

The cytotoxic effects of the rubropunctatin/ $\beta$-cyclodextrin inclusion complex and rubropunctatin solubilized with $0.4 \%$
DMSO were further quantified through flow cytometry. HeLa cells were double-labelled by Annexin-V-FITC/PI after treatment, which made it possible to distinguish and quantitatively analyze non-apoptotic cells (Annexin V-FITC negative/PI negative, C3), early apoptotic cells (Annexin V-FITC positive/PI negative, C4), late apoptotic/necrotic cells (Annexin V-FITC positive/PI positive, C2) and dead cells (Annexin V-FITC negative/PI positive, $\mathrm{C} 1) .{ }^{\mathbf{4 5 , 4 6}}$

As we can see from Fig. 8, the untreated cells (C3) were primarily Annexin V and PI negative, indicating that they were viable and not undergoing apoptosis either in the group containing the inclusion complex (Fig. 8b) or in that containing rubropunctatin solubilized with (Fig. 8a) $0.4 \%$ DMSO. In contrast, all of the treated cells in the group of the inclusion complex and rubropunctatin solubilized with $0.4 \%$ DMSO resulted in a significant increase in the HeLa apoptotic population and a decrease in the non-apoptotic population. Compared to the treatment with rubropunctatin solubilized with $0.4 \%$ DMSO, the data (Fig. $8 \mathrm{c}$ ) evidenced that the inclusion complex had almost the same effect on HeLa cells in inducing apoptosis, that is $95.7 \pm 1.7 \%$ vs. $98.5 \pm 0.8 \%$ apoptosis, including early apoptotic cells and late apoptotic/necrotic cells at $50 \mu \mathrm{mol} \mathrm{L}{ }^{-1}$.

To summarize, we can reach the same conclusion as that from the MTT assay, which is that the rubropunctatin/ $\beta$-cyclodextrin inclusion complex could make a great contribution to the improvement of the bioavailability of rubropunctatin.

\section{Conclusions}

The present study demonstrates that rubropunctatin was complexed with $\beta$-cyclodextrin to form an inclusion complex, which was certified by the results obtained using FESEM, FT-IR and $\mathrm{XRD}$. The molecular docking study revealed two key hydrogen bond interactions between rubropunctatin and $\beta$-cyclodextrin. The water solubility of rubropunctatin was found to be remarkably increased by complexation with $\beta$-cyclodextrin. The average particle size of the inclusion complex was $121.87 \pm$ $2.13 \mathrm{~nm}(n=3)$ with a good PDI $(0.320 \pm 0.017)$, while the potential value was $-27.7 \pm 0.32 \mathrm{mV}(n=3)$. Under light irradiation for $4 \mathrm{~h}$, the preservation rate of the rubropunctatin/ $\beta$ cyclodextrin inclusion complex was still greater than $70 \%$, while that of rubropunctatin was only $10.17 \%$, indicating that the inclusion complex sharply improved the light stability of rubropunctatin. In the in vitro efficacy studies, the rubropunctatin/ $\beta$-cyclodextrin inclusion complex exhibited comparable cytotoxicity against HeLa cells with an $\mathrm{IC}_{50}$ of $39.37 \pm 1.03$ $\mu \mathrm{mol} \mathrm{L}{ }^{-1}$, which was close to that of rubropunctatin solubilized with $0.4 \%$ DMSO $\left(26.60 \pm 0.64 \mu \mathrm{mol} \mathrm{L}^{-1}\right)$. This demonstrated that the inclusion complex not only retained the anti-cancer activity of rubropunctatin, but also greatly enhanced the bioavailability of rubropunctatin because the use of organic solvent was avoided, which was similarly testified by the Annexin V-FITC/PI detection.

Our study establishes that the rubropunctatin/ $\beta$-cyclodextrin inclusion complex provides an alternative means of overcoming the low aqueous solubility and light instability of 
rubropunctatin. On the other hand, the inclusion complex would be very likely to be regarded as a promising rubropunctatin delivery vehicle for future chemotherapy studies involving HeLa cells.

\section{Conflicts of interest}

The authors declare that they have no conflict of interest. This article does not contain any studies with human participants or animals performed by any of the authors. Informed consent was obtained from all individual participants included in the study.

\section{Acknowledgements}

This work was supported by Natural Science Foundation of Fujian Province of China (No. 2017J01854), Fujian Province Young and Middle-aged Teacher Education Research Project (JAT160655), and the Marine High-tech Industry Development Special Project of Fujian Province of China (Min Marine Hightech [2015]01).

\section{References}

1 M. Y. Hong, N. P. Seeram, Y. Zhang and D. Heber, J. Nutr. Biochem., 2008, 19, 448-458.

2 C. Wang, D. Chen and J. Qi, Biochemistry and Molecular Mechanisms of Monascus Pigments, John Wiley \& Sons, Inc., 2017.

3 Y. W. Hsu, L. C. Hsu, Y. H. Liang, Y. H. Kuo and T. M. Pan, J. Agric. Food Chem., 2010, 58, 8211-8216.

4 R. J. Chen, C. M. Hung, Y. L. Chen, M. D. Wu, G. F. Yuan and Y. J. Wang, Free Radical Biol. Med., 2012, 60, 7185-7193.

5 G. Jin-Ming, Y. Sheng-Xiang and Q. Jian-Chun, Chem. Rev., 2013, 113, 4755-4811.

6 Y. Zheng, Y. Xin, X. Shi and Y. Guo, Appl. Microbiol. Biotechnol., 2011, 88, 1169-1177.

7 Y. Zheng, Y. Zhang, D. Chen, H. Chen, L. Lin, C. Zheng and Y. Guo, J. Agric. Food Chem., 2016, 64, 2541-2548.

8 R. Karwal, T. Garg, G. Rath and T. S. Markandeywar, Crit. Rev. Ther. Drug Carrier Syst., 2016, 33, 1-39.

9 Y. Javadzadeh, B. Jafari-Navimipour and A. Nokhodchi, Int. J. Pharm., 2007, 341, 26-34.

10 T. R. Kommuru, B. Gurley, M. A. Khan and I. K. Reddy, Int. J. Pharm., 2001, 212, 233-246.

11 F. Nowroozi, S. Dadashzadeh, H. Soleimanjahi, A. Haeri, S. Shahhosseini, J. Javidi and H. Karimi, Nanomedicine, 2018, DOI: 10.2217/nnm-2018-0091.

12 M. R. de Freitas, L. A. Rolim, M. F. Soares, P. J. Rolim-Neto, M. M. de Albuquerque and J. L. Soares-Sobrinho, Carbohydr. Polym., 2012, 89, 1095-1100.

13 S. Li, Y. Li, Z. Bing, Z. Wei, X. Wang and D. Bai, RSC Adv., 2018, 8, 25867-26431.

14 X. Li, L. Xie, X. Yang and X. Nie, RSC Adv., 2018, 8, 4032140329.

15 A. Kulkarni, W. Deng, S. Hyun and D. H. Thompson, Bioconjugate Chem., 2012, 23, 933-940.
16 Z. Li, M. Wang, F. Wang, Z. Gu, G. Du, J. Wu and J. Chen, Appl. Microbiol. Biotechnol., 2007, 77, 245.

17 F. W. Merkus, J. C. Verhoef, E. Marttin, S. G. Romeijn, V. D. K. Ph, W. A. Hermens and N. G. Schipper, Adv. Drug Delivery Rev., 1999, 36, 41-57.

18 L. Zhong, C. Bo, Y. Hu, Y. Zhang and G. Zou, Food Chem., 2009, 113, 17-20.

19 V. A. Marcolino, G. M. Zanin, L. R. Durrant, M. D. T. Benassi and G. Matioli, J. Agric. Food Chem., 2011, 59, 3348-3357.

20 E. M. Martin Del Valle, Process Biochem., 2004, 39, 10331046.

21 P. Jansook, N. Ogawa and T. Loftsson, Int. J. Pharm., 2017, 535, 272-284.

22 B. G. Woodcock, D. Acerbi, P. G. Merz, S. Rietbrock and N. Rietbrock, Eur. J. Rheumatol. Inflammation, 1993, 12, 12.

23 F. S. Bandarkar and P. R. Vavia, Drug Dev. Ind. Pharm., 2011, 37, 1318-1328.

24 J. S. Torne and P. R. Vavia, J. Inclusion Phenom. Macrocyclic Chem., 2006, 56, 253-259.

25 R. Li, X. Zhang, Q. Zhang, H. Liu, J. Rong, T. Mei, Z. Rong and J. Zhao, J. Appl. Polym. Sci., 2016, 133, 43072.

26 T. Loftsson and M. E. Brewster, J. Pharm. Pharmacol., 2010, 62, 1607-1621.

27 L. J. Yang, Q. Chang, S. Y. Zhou, Y. H. Yang, F. T. Xia, C. Wen, M. Li and X. D. Yang, Dyes Pigm., 2018, 150, 193-201.

28 A. Zeynep, K. Semran Ipek, D. Engin and U. Tamer, Food Chem., 2016, 197, 864.

29 Y. Zheng, Y. Xin, X. Shi and Y. Guo, J. Agric. Food Chem., 2010, 58, 9523-9528.

30 Z. Aytac, Z. I. Yildiz, F. Kayaci-Senirmak, N. O. S. Keskin, S. I. Kusku, E. Durgun, T. Tekinay and T. Uyar, J. Agric. Food Chem., 2016, 64, 7325-7334.

31 H. Peng, T. Wang, P. Xie, T. Chen, H. W. He and J. Wan, J. Agric. Food Chem., 2007, 55, 1871-1880.

32 G. M. Morris, R. Huey, W. Lindstrom, M. F. Sanner, R. K. Belew, D. S. Goodsell and A. J. Olson, J. Comput.Aided Mol. Des., 2010, 30, 2785-2791.

33 A. Toshihiro, T. Harukuni, Y. Ken, U. Motohiko, K. Ayaka, S. Naoyuki, S. Takashi, T. Nobukazu and N. Hoyoku, J. Agric. Food Chem., 2005, 53, 562.

34 A. Pant and J. S. Negi, Eur. J. Pharm. Sci., 2018, 112, 180-185. 35 A. Pant and J. S. Negi, Eur. J. Pharm. Sci., 2018, 112, 180-185. 36 G. W. Lu and P. Gao, Handbook of Non-Invasive Drug Delivery Systems, 2010, pp. 59-94.

37 G. W. Lu and P. Gao, Handbook of Non-Invasive Drug Delivery Systems, 2010, pp. 59-94.

38 S. Siva, S. K. Nayaki and N. Rajendiran, Spectrochim. Acta, Part A, 2017, 174, 349.

39 D. Bonenfant, P. Niquette, M. Mimeault, A. Furtosmatei and R. Hausler, Water Res., 2009, 43, 3575-3581.

40 A. Abou-Okeil, M. Rehan, S. M. El-Sawy, M. K. El-Bisi, O. A. Ahmed-Farid and F. A. Abdel-Mohdy, Eur. Polym. J., 2018, 108, 304.

41 C. Anselmi, M. Centini, M. Ricci, A. Buonocore, P. Granata, T. Tsuno and R. M. Facino, J. Pharm. Biomed. Anal., 2006, 40, 875-881. 
42 B. Liu, W. Li, J. Zhao, Y. Liu, X. Zhu and G. Liang, Food Chem., 2013, 141, 900-906.

43 D. Xu, X. Wang and L. Ding, Carbohydr. Polym., 2011, 83, 1257-1262.

44 N. Qiu, X. Cheng, G. Wang, W. Wang, J. Wen, Y. Zhang, H. Song, L. Ma, Y. Wei and A. Peng, Carbohydr. Polym., 2014, 101, 623-630.
45 S. Chen, A. C. Cheng, M. S. Wang and P. Xi, World J. Gastroenterol., 2008, 14, 2174-2178.

46 W. Zhang, Y. Liang, L. Li, X. Wang, Z. Yan, C. Dong, M. S. Zeng, Q. Zhong, X. K. Liu and J. Yu, Cell Proliferation, 2019, DOI: 10.1111/CPR.12536. 